Meta

Journal des traducteurs

Translators' Journal

\title{
The Language of Plays Translated into Hebrew from English and French - A Cultural-Stylistic Study
}

\section{Rina Ben-Shahar}

Volume 43, numéro 1, mars 1998

La traduction et l'interprétation en Israël

Translation and Interpreting in Israel

URI : https://id.erudit.org/iderudit/002059ar

DOI : https://doi.org/10.7202/002059ar

Aller au sommaire du numéro

Éditeur(s)

Les Presses de l'Université de Montréal

ISSN

0026-0452 (imprimé)

1492-1421 (numérique)

Découvrir la revue

Citer cet article

Ben-Shahar, R. (1998). The Language of Plays Translated into Hebrew from English and French - A Cultural-Stylistic Study. Meta, 43(1), 54-67.

https://doi.org/10.7202/002059ar
Résumé de l'article

Cette étude traite des caractéristiques linguistiques et stylistiques du théâtre hébraïque traduit de l'anglais et du français entre la fin des années 1940 et la fin des années 1970. Cette période cruciale de 30 ans fut marquée par les grands changements qui affectèrent la langue hébraïque, la littérature et le théâtre. Le corpus étudié comprend 180 pièces dont des pièces en un acte, traduites en hébreu, soit 125 (américaines et anglaises) traduites de l'anglais et 55 traduites du français. (Ces chiffres reflètent la place relative occupée par ces deux sous-systèmes dans le théâtre israélien.) L'étendue du corpus a permis une description générale des phénomènes stylistiques du genre. On a pu tirer des conclusions concernant les phénomènes et les processus sociolittéraires et sociothéâtraux qui affectaient les pièces de théâtre de la période traitée. Le style des pièces traduites a été étudié tant du point de vue synchronique que diachronique. 


\title{
THE LANGUAGE OF PLAYS TRANSLATED INTO HEBREW FROM ENGLISH AND FRENCH - A CULTURAL-STYLISTIC STUDY
}

\author{
RINA BEN-SHAHAR \\ Haifa University, Haifa, Israel
}

\begin{abstract}
Résumé
Cette étude traite des caractéristiques linguistiques et stylistiques du théâtre hébraïque traduit de l'anglais et du français entre la fin des années 1940 et la fin des années 1970. Cette période cruciale de 30 ans fut marquée par les grands changements qui affectèrent la langue hébraïque, la littérature et le théâtre. Le corpus étudié comprend 180 pièces dont des pièces en un acte, traduites en hébreu, soit 125 (américaines et anglaises) traduites de l'anglais et 55 traduites du français. (Ces chiffres reflètent la place relative occupée par ces deux sous-systèmes dans le théâtre israélien.) L'étendue du corpus a permis une description générale des phénomènes stylistiques du genre. On a pu tirer des conclusions concernant les phénomènes et les processus sociolittéraires et sociothéâtraux qui affectaient les pièces de théâtre de la période traitée. Le style des pièces traduites a été étudié tant du point de vue synchronique que diachronique.
\end{abstract}

\begin{abstract}
This paper deals with the linguistic and stylistic characteristics of Hebrew drama, translated from English and French, from the late 1940s to the late 1970s. During this significant thirty-year period, great changes took place in the Hebrew language, literature and theatre. The corpus of the research consists of 180 translated plays and short plays; 125 plays translated from English (American and English plays) and 55 plays translated from French. (These numbers reflect the relative position of the two sub-systems in the Israeli theatre.) The wide scope of the corpus enabled an overall description of the stylistic phenomena of this genre, and led to conclusions concerning the socioliterary and sociotheatrical phenomena and processes that affected plays from the period under discusssion. The style of the translated plays has been studied from both the synchronic and diachronic points of view.
\end{abstract}

\section{CULTURAL AND LINGUISTIC BACKGROUND}

The problem of translating drama dialogues is particularly acute when texts are translated from literature in a language possessing an unbroken speech tradition and a consolidated tradition of written simulation of natural speech phenomena, into the literature of a renovated language such as Hebrew, whose spoken vernacular is relatively undeveloped, and where very few similar traditions have evolved.

As a result of the unique history of the Hebrew language, which had survived for a long time as a written language only, lacking the variegated functions of spoken language, Hebrew literature inevitably drew solely on written sources, thus facing special difficulties in delivering speech.

By the 1940's Palestine had become the center of Hebrew literature, where most Hebrew writers and readers lived. At that time, Hebrew had gradually become a living language, and its users were now offered language varieties previously unavailable to them. And yet the new lin- 
guistic means drawn from every-day life, now at the disposal of Hebrew, were not necessarily put to immediate literary use. Modern Israeli literature had no previous tradition to fall back on when it came to writing dialogues based on principles of spoken language, and Hebrew writers and translators were completely inexperienced in handling dialogue (Even-Zohar 1982, 1985; Ben-Shahar 1994). Hebrew literature and theatre needed to gain more time and experience before writers could adopt means of expression from spoken Hebrew, and develop models to represent them in plays.

Moreover, the normative attitude which had evolved in Hebrew culture as a result of the prolonged dependence of both language and literature on written texts, prevented elements of spoken Hebrew from penetrating into literature. This attitude was also reflected by the writers' and translators' high awareness of written language rules and their tendency to ignore the special principles and needs of the oral medium. In fact, the Hebrew spoken in Israel was conceived of as incorrect language unworthy of use in literature and theatre and, for many, even unworthy of everyday use.

It may therefore be claimed that the formation of dialogue was one of the most difficult linguistic challenges faced by Hebrew culture. When the number of speakers of Hebrew as mother tongue increased, and when the Hebrew literature and theatre began to face subjects and background materials dealing with contemporary reality of life in Israel, the traditional linguistic repertoire was perceived as more and more strange and artificial, calling out for change. Writing and translating plays, consisting of dialogues meant for an audience, has made Hebrew playwrights and translators cope with transmitting speech in a more decisive manner than in any other literary genre.

\section{Linguistic-Stylistic Options}

During the forties some sections of Hebrew literature began deviating from the traditional linguistic model using selectively new options from the spoken language, while other sections adhered to the super-standard written language model. In shaping dialogue three main options were made use of:

1) The use of standard and super-standard written Hebrew, ignoring the principles of spoken language in general, and those of spoken Hebrew in particular.

2) Shaping dialogue as a distinct pseudo-spoken variety, differentiated from standard Hebrew. This was not based on a real differentiation between spoken and written Hebrew. Drama translators tended to embed many invented elements in the dialogue, either calques of original text elements, or intra-Hebrew inventions, such as invented lexemes or grammatically incorrect structures, not based on authentic structures of spoken Hebrew. By creating ad hoc dialogues the translators tried, on the one hand, to provide a make-believe of spoken language, and on the other hand, to avoid spoken Israeli Hebrew (Ben-Shahar 1983).

3) The use of authentic elements of the spoken variety arranged according to actual principles of spoken Hebrew. This mode has gained ground in Hebrew translation especially since the seventies.

These three different modes of translating dialogues are stylistic options, rather than mutually exclusive modes of behaviour. In drama translated into Hebrew one may thus encounter texts featuring two modes or all three. In fact, dialogue language, where no established patterns of formation had existed in Hebrew, became an experimentation field for both writers and translators (Ben-Shahar 1994). Generally speaking, until the late sixties, modes 1 and 2 prevailed in Hebrew plays translated from English and French, gradually substituted by mode 3 . Those who have adopted mode 3 usually aim at a functional transfer of linguistic means of the source text, and tend not to subject their translation to the constraint of acceptibility. 


\section{THE POSITION OF TRANSLATED DRAMA IN THE HEBREW LITERARY AND THEATRICAL SYSTEMS}

Until the sixties, original drama was still an undeveloped genre of Israeli literature and theatre (Shaked 1960; Ofrat 1975). The lack of original plays was substituted by translations, especially from English. Plays were translated more as a theatrical activity than as a part of literary activity (Ben-Shahar 1983, 1995). Thus most of the plays translated from English and French into Hebrew were translated for stage performance. Such translations were therefore not published in book form or in literary magazines, but were copied for limited distribution as theatrical working texts. Translations were directly commissioned from the translators by the theatres, and there must have been some relationship between the translator and the theatre. The fact that translated drama pertained to the theatrical system may have made translators take the special needs of the stage performance into consideration to a certain extent (for example, the vocal stage performance represented sometimes by phonetic imitation of spoken language, Ben-Shahar 1995). However, most theatre translators until the late sixties were also some of the established writers and poets of that time, who also translated poetry and narrative fiction into Hebrew, and were thus considerably bound to written language norms, following the stiff linguistic-stylistic model already crystallized within the Hebrew literary tradition.

During the fifties original Hebrew drama and narrative fiction already attempted to break through the stiff linguistic model employed by writers till then, and to draw closer to spoken Hebrew. At the same time, translated drama still adhered to older norms, earlier formed by literary tradition, tending to ignore the Israeli vernacular. Hebrew playwrights, also active as translators, thus usually employed as original writers considerably different norms from those which they used as translators (Ben-Shahar 1983). Hence the system of translated plays was epigonic with regard to the system of the original Hebrew plays that were performed.

During the sixties and seventies some new translators emerged, who tended to use spoken Hebrew. Some of those were neither writers nor playwrights, but rather professional translators, well-versed in theatrical life. Most of them were new on the scene, and had not translated plays from English and French during the fifties. Thus, the gap between original Hebrew plays and those translated from English, concerning the extent to which spoken language was used, was closed (mode 3 mentioned above). Plays translated from English broke free of peripheral system patterns due to the central position they occupied in the Israeli theatre. Spoken language also increased in plays translated from French, but since this sub-system occupied a peripheral position in both Israeli literature and theatre, this process was more moderate and slow than it was in plays translated from English, as well as in original Hebrew plays. (See Even-Zohar (1990b) and Toury (1995) on the relationship between the position of a (sub)system within the recipient culture, and the literary repertoire of its products.)

\section{THE LINGUISTIC MODEL}

The linguistic model, adhered to by translators up to the mid sixties, was relatively limited, mainly containing written Hebrew devices. Various samples of spoken and written language during those years show that there existed in Hebrew spoken and written sub-languages as clearly separate options, but translators mainly clung to the safe system of standard and super-standard Hebrew (mode 1 mentioned above). During this period there seems to have existed a great gap between the Hebrew vernacular and literary dialogue in translated plays. Translators generally did not make their translations adequate reproductions of original texts, but rather accepted the current norms of Hebrew literary tradition. 
As a result, stylistic differentiation between different characters or situations, shaped in the source plays, were often erased in Hebrew translations, by means of elevating sub-standard and standard styles of the source text. The inevitable effect was a stylistic uniformity of Hebrew translated plays.

Here and there, translators deviated from the written language model by selectively introducing into the dialogue elements pertaining to the contemporary spoken vernacular, considered at that time as representing spoken language. Lexical elements were the first spoken language elements to enter play language, sometimes exclusively so. Yet they were usually embedded in a high-style grammatical context. The result was a mixed artificial language which combined different stylistic levels and demonstrated a discrepancy between the marked elements of sub-standard spoken Hebrew (usually lexemes), on the one hand, and super-standard written language, on the other (Ben-Shahar 1983, 1994, 1995). Such language did not conjure up an impression of authentic conversation even when the translator actually intended to convey such an impression (mode 2 mentioned above). Hebrew translators tended to impose on the lexicon the role of representing speech, which may be explained by a heightened awareness of the lexicon and minimal awareness (or even unawareness) of other linguistic domains such as syntax, rhythm and intonation, which characterize language users in general, not only translators into Hebrew.

Translated plays include many invented elements, be they calques of source text structures, or items invented through intra-Hebrew techniques. Dialogue language, conceived by the Hebrew translator as a "deviation from the accepted standard," is especially prone to interference of the source text. Translators often prefer to provide a make-believe atmosphere of spontaneous conversation to the dialogue of the play through syntactic, grammatical, lexicosemantic and phonetic-graphic calques of the source text rather than to employ authentic spoken Hebrew means (mode 2 mentioned above). In many cases both calques and authentic spoken elements are indiscriminately used in a single text.

The main techniques of intra-Hebrew inventions in the language of translated drama are:

1) Inventing a word based on an existing Hebrew root, structured in a grammatical pattern not previously used for this root.

This method, which had been commonly used in previous generations of Hebrew literature, disappeared almost completely from Hebrew original narrative fiction and drama in the period under discussion, but was still often used in translated texts.

2) Use of deviant spoken or written language fixed expressions. Deviating from a spoken language fixed expression elevates its style (while retaining some traces of its colloquial nature), thereby making it fit for literary use, whereas deviating from a written language fixed expression lowers its style, making it look more colloquial.

3) Creating grammatical mistakes that do not reflect authentic phenomena of spoken Hebrew. Such grammatical inventions stem from a conviction, mainly shared by playwrights and translators of the fifties, that spoken language is basically wrong, so that any wrong language is spoken language.

In those few instances where translators of the fifties and the early sixties go so far as to employ this method, they do it solely in depicting the style of primitive uneducated characters. The grammatically invented mistakes serve to translate linguistic elements of dialect clearly marked as low spoken dialect in the source text language. In many cases the translators embed in the dialogue both invented mistakes and authentic spoken deviations from standard Hebrew. Introducing low-class dialects seems to have legitimized using non-normative spoken Hebrew, in a similar manner sub-standard language was first introduced into European comedy.

During the sixties and seventies invented elements decreased in frequency in translated plays, yet translation through calques of source text elements was still common in the field of 
vocatives, expletives, exclamations and void pragmatic connectives, to the extent that their nature in translated plays is one of the major elements indicating that these plays are translated plays. The main reasons for the foreign nature of vocatives, expletives, exclamations and void pragmatic connectives in translated plays are as follows:

1) Translators' tendency to formal equivalence translation makes them translate such elements whenever they occur in a source text, even where their use in Hebrew is less frequent than it is in the source language (Ben-Shahar 1987, 1994).

2) Translators regarding language as mainly carrying a referential function. Hence there follows scant awareness of the existence of elements possessing an expressive or phatic function, and a difficulty in finding an appropriate style for them. Words and phrases possessing those functions are often translated literally, namely, according to their referential function (Ben-Shahar 1987, 1994).

3) Language voids in Hebrew in those fields during the period when the translations were written (Ben-Shahar 1987, 1994).

Gradually the linguistic model became more flexible. Translators during the sixties, and particularly those of the seventies, started using previously ignored linguistic options, borrowed from the low levels of Israeli Hebrew. Incorporation of spoken language markers from different linguistic domains (the lexical, the grammatical-syntactical, etc.) prevents gaps between different stylistic levels of the dialogue, so typical of the plays of the forties and fifties. Lexical and syntactic elements of sub-normative language levels are mainly borrowed, whereas normative written language elements usually supply the morphological level. One may say that, during the seventies also, the linguistic options that actually existed in Hebrew were more variegated than those used in translated plays.

\section{EXAMPLES AND COMMENTS}

Below are examples from plays translated into Hebrew from English and French, demonstrating some of the linguistic model principles described above. The Hebrew examples are quoted here in transliteration and literal back translation into English (in square brackets).

\section{A. Calques of source text structures}

1. Afternoon, gentlemen. Afternoon maam. (Shaw $1941: 64$ )

Hebrew translation:

$\begin{array}{llll}\text { lehitraot, } & \text { adonim, } & \text { 'raot, } & \text { gveret. (p. 64) } \\ \text { [see you, } & \text { sirs, } & \text { 'you, } & \text { madam.] }\end{array}$

The spoken English omission of the word good from the greeting good afternoon was imitated by the Hebrew translator, by using an invented contracted form of the Hebrew greeting lehitraot (lehitraot raot). Since such a contracted greeting does not exist in Hebrew, the translator translated the first occurrence of the English greeting by the full standard word, and only the second was translated by the invented contracted form, thus ensuring the reader's/spectator's right interpretation of the artificial element. Surprisingly enough, the translator preferred to ignore the authentic spoken Hebrew contraction of the same greeting lehit.

2. - We were talking about my manhood.

- We still are. (Jones 1964 : 26) 
Hebrew translation:

$\begin{array}{lll}\text { - dibarnu } & \text { al } & \text { ha-gavriut sheli. } \\ \text { [we talked } & \text { about } & \text { my manhood.] } \\ \text { - anaxnu } & \text { adayin. (p. 11) } & \\ \text { [we } & \text { still.] } & \end{array}$

In example (2) the translator produces a syntactic calque of the source text utterance, where the main verb is omitted (to talk), and the auxiliary verb (to be) is retained in the case of potential verbal repetition (we still are). The Hebrew translator omits the main verb as well, but since the Hebrew sentence does not contain an auxiliary verb, the translator comes up with an artificial elliptic sentence: we still.

3. Tu as d'énormes qualités, mon petit Maréchal. (Ionesco $1975: 23$ )

Hebrew translation:

$\begin{array}{llll}\text { sgulot kabirot } & \text { yesh lexa, } & \text { alufi } & \text { ha-paut. (p. 10) } \\ \text { [great qualities } & \text { you have, } & \text { my tiny } & \text { Brigadier.] }\end{array}$

In the above example the vocative phrase mon petit Maréchal was literally translated into Hebrew, yielding a non-authentic Hebrew phrase. The Hebrew word paut (tiny), which was chosen from among other synonyms due to its phonetic similarity to the equivalent element in the French original (petit/paut), is used in Hebrew as an attribute of a small child, but never of an adult.

4. Hey, brother! (Jones $1964: 38$ )

Hebrew translation:

halo, axa! (p. 17)

[hallo, brother!]

The word axa is a typical vocative of Hebrew translated dialogues. It translates the referential meaning of the English vocative brother, but it does not correspond to the source element function. Axa is structured in a grammatical Aramaic pattern, and hence marked as a high-style element in Hebrew, never used in everyday conversation. As to the greeting hallo, it is never used in Hebrew in face to face communication, but only in phone calls. One can see that the Hebrew translators tend to insert foreign and artificial elements into the translated dialogue, ignoring authentic usage.

\section{B. Inventions through intra-Hebrew techniques}

5. The weather's so blasted bloody awful. (Pinter $1968: 10$ )

Hebrew translation:

$\begin{array}{llll}\text { mezeg ha-avir } & \text { mexurban } & \text { u-mexurkak } & \text { nora. } \text { (p. 40) } \\ \text { [the weather } & \text { bloody } & \text { and "insected" [= insect-like] } & \text { very much.] }\end{array}$

The word mexurkak which translates the source text expletive blasted is an invented lexeme based on the Hebrew word insect, inflected in a passive verb pattern, a grammatical form which is not used in Hebrew for this specific root. It seems that the translator invented this word in order to retain the word-play (blasted bloody/mexurban u-mexurkak) of the source text. 
The technique of inventing a word based on an existing Hebrew root (or word), structured in a grammatical pattern not previously used for this root, was common and generative in literary translation into Hebrew, particularly, as mentioned earlier, in the fields of expletives, vocatives, exclamations and void pragmatic connectives.

6. Hey old pisser. (Baldwin $1964: 7$ ).

Hebrew translation:

hey mashtinon. (p. 6)

[hey pisser (an invented word).]

The word mashtinon does not exist in the Hebrew vocabulary. The translator formed it by adding a diminutive suffix to the present tense singular form mashtin, except that this suffix is not added freely to every Hebrew word, nor so to the form mashtin.

\section{Deviating from fixed expressions}

7. Occupe-toi de tes affaires. (Ionesco $1954: 187$ )

Hebrew translation:

d'ag la-'asakexa ata ve-al titxovet apxa le-iskeihem shel axerim (p. 7)

[mind your own business and don't poke your nose into the affairs of other(s) [people]].

In the above example the spoken Hebrew fixed expression lidxof et ha-afldaxaf et ha-af was stylistically elevated by lexical as well as grammatical means, thus legitimized for literary use. The lexeme lidxofldaxaf (to poke) in the context of the above expression is marked in Hebrew as a sub-standard vulgar element. Hebrew translators tend to replace it by a super-standard verb which is phonetically similar to it - litxov/taxav (inclined in the second person singular, tidxof is replaced by titxov). This euphemistic replacement may be seen as an automatic stock replacement, since different translators apply it to the same expression, as well as for other spoken language expressions where the same sub-standard verb occurs.

Along with the lexical change, a grammatical mean of written Hebrew was used in order to elevate the style of the above sub-standard expression: the synthetic possessive morpheme ( apxa $=$ your nose) was preferred to the spoken language analytic possessive (ha-af [ap] shel $x a$ ). The result is a mixed-style expression, which, although it echoes the sub-standard expression which lies at its basis, does not reflect authentic speech. It should be noted that the pseudo-spoken expression in example (7) is inserted into a super-standard grammatical-syntactical context, as is often the case in plays translated into Hebrew. Following is a similar example:

8. Now, up your arse. (Pinter $1968: 34)$

Hebrew translation:

et ha-xoxmot shelxa txov ba-taxat. (p. 35)

[your clever words poke [sing. masc. imperative] in the arse.]

Here, too, the sub-standard verb lidxof (imperative $d x o f$ ) was replaced by the super-standard verb litxov (imperative txov), this time in another spoken Hebrew expression.

9. Si, vous venez de vous le permettre! (Ionesco 1975b : 37) 
Hebrew translation:

$\begin{array}{lll}\text { ken, } & \text { ze axshav } & \text { hirsheta leatsmexa! (p. 16) } \\ \text { [yes, } & \text { you have just [now] } & \text { allowed yourself!] }\end{array}$

In this case the translator deviated from a written language fixed expression, lowering its style by substituting its second word, marked as super-standard (ata $[$ ata $]=$ now) by a neutral standard synonym (axshav): ze ata ze axshav.

\section{Invented grammatical mistakes}

10. She beg me make charm. (Miller $1971: 46$ )

Hebrew translation:

$\begin{array}{llll}\text { hi } & \text { levakesh } & \text { mimeni } & \text { la'asot kesem. (p. 37) } \\ \text { [she } & \text { to beg } & \text { me } & \text { to make charm.] }\end{array}$

The translator uses here the infinitive of the verb (levakesh $=$ to beg) instead of the past form of the third person feminine. This deviation lies on the borderline of intra-Hebrew invention and calque of the source text, since it is obvious that the position of the Hebrew deviation is dictated by the position of the source utterance grammatical deviation. The invented dialect in the Hebrew translation conveys the sub-standard dialect of the black woman in the source play.

11. I don't li-ike dees voyage. (O'Neill $1923: 88$ )

Hebrew translation:

$\begin{array}{lll}z \boldsymbol{e} & \text { nesi'a lo motset xen } & \text { ba-einayim sheli. (p. 3) } \\ \text { [this } & \text { voyage does not find grace } & \text { in my eyes.] }\end{array}$

The sailors' dialect in the above example (shaped in the source text mainly by phoneticgraphic means) is rendered into Hebrew by an artificial incorrect language, which does not reflect any spoken Hebrew dialect. The grammatical deviations: gender disagreement between the demonstrative ze (sing. masc.) and nesi'a (sing. fem.); substituting the synthetic possessive pronoun added to the noun einayim (eyes) by the analytic possessive pronoun, which is never used in the quoted fixed expression.

\section{The rhetorical-stylistic model}

The rhetorical-stylistic model that affected the linguistic decisions of translators into Hebrew during the forties and fifties, and, to a certain extent, during the sixties and seventies as well, actually inspired the translators to demonstrate rich language, richness of Hebrew as well as richness of the individual translator's language (and see Toury 1977 for 1930-1945, BenShahar for 1948-1975, Weissbrod 1989 for 1958-1980). The principles of this model are the following:

\section{Using grammatical and lexical elements possessing high stylistic value.}

Most translators of the forties and fifties consistently avoided using common and neutral linguistic elements and preferred the rarer elements out of the language alternatives. The high style norm was so deeply rooted during this period, that using spoken language elements required special awareness on the part of the translators, and is not to be regarded as subconscious infiltration of the spoken substratum. A large part of the rare linguistic elements are 
translations of elements indicating every-day life items in the source text. The rare element, usually borrowed from Hebrew written sources, often carries a less clear denotation than the original text item it replaces. Hence, the stylistic effect seems to be of greater importance for translators of this period than accuracy in transmitting information.

\section{Using high-style fixed expressions.}

Written language fixed expressions are very common in Hebrew translated plays. They usually replace stylistically neutral free phrases in the source text. The intensive use of fixed expression from the Hebrew written sources is a major characterictic which lends the language of translated plays its learned, elevated style.

3. Using redundant sequences of two fixed synonymous nouns, or verbs, or adverbs etc., preferred to single elements or free phrases.

Translated plays continue the Hebrew tradition of using redundant fixed sequences of two synonymous words. On the one hand, the phenomenon of using such sequences is related to the phenomenon of using written language fixed expressions, while on the other, it is to be regarded as an expression of the Hebrew writer's and translator's tendency to use language redundantly for sheer stylistic effect.

4. Avoiding verbal repetition and preferring linguistic variety, by using synonyms and even deletion.

The stylistic principle of avoiding verbal repetition primarily results from the Hebrew stylistic tendency to demonstrate rich language. Repetitions in the source language text are sometimes ignored by the translator as a result of insufficient awareness of the syntagmatic patterns of the text.

5. Using complete, well-formed syntactic structures.

During the forties and fifties a Hebrew stylistic norm prevailed that instructed playwrights and translators to avoid using incomplete syntactic structures. The influence of this norm finds expression in regulated shifts, made by translators from source text into Hebrew translated text. The major shifts are the following:

completing syntactic ellipsis and incomplete utterances; omitting void pragmatic connectives; replacing free word order of the sentence by ordinary word order; replacing asyndetic conjunctions by syndetic conjunctions, hence filling pauses between elements of the sentence; replacing paratactic syntax by hypotactic syntax, hence explicitly exposing the logical relations between the parts of the sentence.

During the sixties and seventies a considerable change took place in the syntactic structuring of the dialogue in original as well as translated plays. Spoken syntactic structures are abundantly introduced into the dialogue of that period. Translators usually tend to retain source text syntactic structures, such as elliptical sentences and incomplete utterances, without completing them to well-formed sentences. Yet, even during this period, translators are still bound to the original text language structure, and the use they make of syntactic structures, deviating from written language norms, usually depends on the existence and position of such specific structures in the original text.

\section{Examples and comments}

A. Using high-style fixed expressions

1. Tu t'es disputé avec tous tes amis [...] avec ton frère. (Ionesco 1975a : 24) 
Hebrew translation:

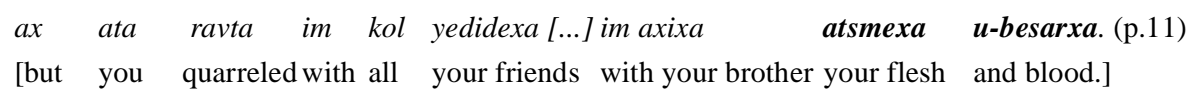

The super-standard fixed expression atsmexa u-besarxa (your flesh and blood) has no equivalent in the source utterance. This manifests the Hebrew translator's tendency to use written language fixed expressions for sheer stylistic effect.

2. Why you got to flit from one thing to another? (Hansberry $1959: 32$ )

Hebrew translation:

$\begin{array}{lll}\text { lama at } & \text { paxaz } & \text { kamayim? (p. 24) } \\ \text { Why are you } & \text { unstable } & \text { as water? } \\ \text { Why are you } & \text { turbulent } & \text { as a flood? }\end{array}$

3. Sounds rather like Daddy, don't you think? (Osborne 1968 : 11)

Hebrew translation:

ha-kol kolo shel aba, lo xen? (p. 6)

[the voice is Daddy's voice, is it not?]

In examples (2) and (3) the translators render source texts spoken as language utterances into Hebrew super-standard utterances, into which Biblical expressions are inserted, alluding to well-known passages in the Bible, which are not relevant to the quoted scenes. In example (2) the translator uses the Biblical phrase paxaz kamayim from Jacob's blessing, referring to Reuben (Genesis 49, 4: "unstable as water" — King James' version; "turbulent as a flood" — The New English Bible). In example (3) the translator uses Isaac words to Jacob: "the voice is Jacob's voice [but the hands are the hands of Esau]" - Genesis 27, 22. It is obvious that the Hebrew translators are seeking a stylistic effect (following the Hebrew literary-linguistic tradition) at the expense of transmitting the meaning and style of the original.

B. Using sequences of two fixed synonyms

4. Je veux bien. (Beckett 1952: 19)

Hebrew translation:

$\begin{array}{ll}\text { ani muxan } & \text { u-mezuman. (p. 6) } \\ \text { [I am ready } & \text { and prepared.] }\end{array}$

5. She is a knockout. (Miller $1957: 63$ )

Hebrew translation:

\begin{tabular}{|c|c|}
\hline $\begin{array}{l}\text { ha-baxura ha-zot } \\
\text { this girl }\end{array}$ & - xaziz va-ra'am. (p. 4) \\
\hline
\end{tabular}

6. Ça n'a jamais existé, Paris, mon petit. (Ionesco 1975a : 18)

Hebrew translation:

$\begin{array}{llll}\text { pariz } & \text { lo hayta } & \text { ve-lo nivre'a, } & \text { paot sheli. (p. 7) } \\ \text { [Paris } & \text { did not exist } & \text { and was not created, } & \text { my tot. }\end{array}$


C. Avoiding verbal repetition

7. - Qu'est-ce qu'on fait maintenant?

- On attend.

- Oui, mais en attendant? (Beckett 1952 : 21)

Hebrew translation:
- ma osim axshav?
[what are we doing now?]
- mexakim.
[waiting.]
- ken, aval ma osim tox tsipiya? (p. 7)
[yes, but what are we doing while expecting?]

Not only did the translator avoid the verbal repetition of the source utterance (different forms of the verb attendre), but he also missed part of the play's title: En attendant [Godot] (mexakim le-godo).

8. Tell me something. I mean just tell me, Rodolpho. (Miller 1963 : 61)

Hebrew translation:

haged li davar exad, rak tagid li rodolpho. (p. 11)

[tell me one thing, just tell me Rodolpho]

The translator refrains from repeating the verb by employing two variations of the Hebrew imperative: the first occurrence (haged li) is the written language imperative, and the second (tagid li) is that of the spoken language.

9. - I don't see nothing moving and neither do you.

- Nothing is moving so you can see it moving, but everything is moving.(Williams $1968: 20$ )

Hebrew translation:

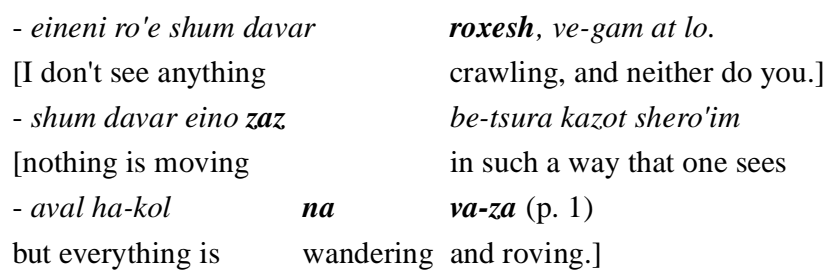

The translator used four different Hebrew lexemes for the source text repeating verb moving: roxesh, zaz, na and $z a$. The last pair of these verbs (nava-za) is a deviated written language fixed expression ( $n a v a-n a d)$.

D. Using complete, well-formed syntactic structures

10. - Et cette nuit, la même chose?

- J'ai le regret de devoir le dire à Monsieur Horace, oui. (Anouilh 1951 : 9) 
Hebrew translation:

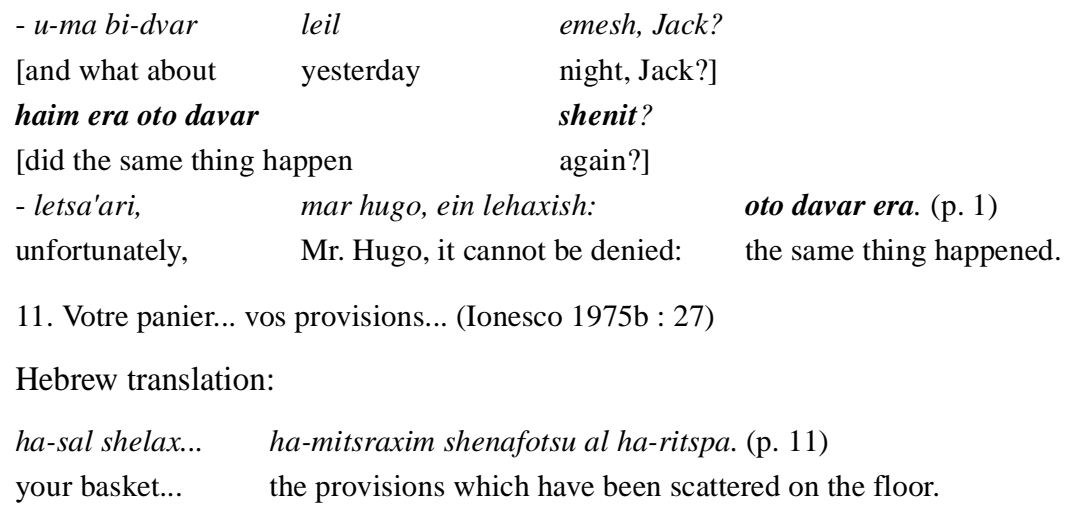

The Hebrew translators' tendency to use complete sentences goes side by side with the general tendency of translators to make their translated text more explicit than the original.

\section{CONCLUSION}

It has been argued here that the formation of dialogue in both original works and translations was one of the most difficult linguistic challenges faced by Hebrew culture. As a result of the prolonged dependence of Hebrew language and literature on written sources, a normative attitude towards language evolved in Hebrew culture. This was reflected in writers' and translators' high awareness of written language means and their tendency to ignore the principles and needs of spoken language.

The low awareness of spoken language also draws on the lack of tradition in simulating a vernacular in Hebrew literature and theatre. Hebrew writers and translators were inexperienced in handling dialogue. Even when Hebrew writers and translators of the fifties and sixties deliberately used some elements of spoken Hebrew, they failed to perceive the various domains of language. Thus, the modes of formulating spoken, or rather pseudo-spoken language, in works written during that period, mainly carried out by means of spoken Hebrew lexical elements, demonstrate a simplistic conception of language where lexemes determine the language level, while grammatical and syntactical-cohesive factors which organize them play but a secondary role.

At the outset of the period under discussion translated drama, in spite of its being more a part of the Israeli theatrical system than of the literary system, behaved as an epigonic system: it adhered to old literary-stylistic norms cristallized in the Hebrew literary tradition. Most translated plays drew on the super-standard Hebrew of the written sources, even when confronted with source texts which made intensive use of spoken language and different dialects. Deviations from normative Hebrew were often made through calque translation of the source text structures. One may say that the interference of source language was stronger in dialogue translation than it was in narrative texts at that period.

In the course of time the normative approach towards language relaxed somewhat, and the tendency towards adequate translation increased. In the seventies translators of Hebrew plays demonstrated a much higher awareness of spoken language, and the linguistic-stylistic model they used was richer and more flexible than previously. Translated plays have increasingly been reflecting more authentic speech.

The present study shows that playwrights and translators do not directly borrow their language models from the everyday living language, but do so rather through media- 
tion of linguistic-stylistic norms formed in literary tradition, whose influence on the playwright's or translator's style is greater than that of his own everyday language usage.

The data of this study reveals a connection between the language of a play and factors such as its being original or translated; it pertains to a certain sub-system of the translated literature system, defined by source languages and source literatures (in our research - drama translated from English/drama translated from French); the play being or not being performed on stage, i.e. the manner of its pertaining to different cultural systems; the translator's identity, i.e. his being a central or peripheral figure, or his being a playwright or only a professional translator, and the time when the play was translated.

\section{References}

BEN-SHAHAR, Rina (1983) : Dialogue Style in the Hebrew Play, Both Original and Translated from English and French, 1948-1975, 1-2. Tel Aviv University, Ph.D. Thesis, Tel Aviv. (Hebrew, English abstract)

BEN-SHAHAR, Rina (1987) : "Terms of Address in Plays Translated from English and French into Hebrew", Bamah (Drama Quarterly), 108, pp. 51-57. (Hebrew)

BEN-SHAHAR, Rina (1994) : "Translating Literary Dialogue: A Problem and Its Implications for Translation into Hebrew", Target, 6 (2), pp. 195-221.

BEN-SHAHAR, Rina (1995) : "The Phonetic Representation of Spoken Language in Modern Hebrew Literature", TTR (Traduction, Terminologie, Rédaction), 7 (2), pp. 245-273.

EVEN-ZOHAR, Itamar (1982) : "The Emergence of Speech Organizers in a Renovated Language: The Case of Hebrew Void Pragmatic Connectives", N. E. Enkvist (Ed.), Impromptu Speech: A Symposium, Abo, Abo Akademi, pp. 179-193.

EVEN-ZOHAR, Itamar (1985) : "Gnessin's Dialogue and Its Russian Models", Slavica Hierosolymitana, 17, pp. 17-36. [A revised version in Even-Zohar 1990 : 131-153.]

EVEN-ZOHAR, Itamar (1990a) : "Polysystem Studies", Poetics Today, Durham, Duke University Press, 11 (1) Spring, pp. 45-51.

EVEN-ZOHAR, Itamar (1990b) : "The position of Translated Literature within the Literary Polysystem", Poetics Today, 11 (1) Spring, pp. 45-51.

OFRAT, Gideon (1975) : Israeli Drama, Jerusalem, Cherikover and the Hebrew University of Jerusalem. (Hebrew)

SHAKED, Gershon (1960) : "Some Aspects of Original Israeli Drama", Bamah (Drama Quarterly), 6 July, pp. 917. (Hebrew)

TOURY, Gideon (1977) : Translational Norms and Literary Translation into Hebrew, 1930-1945, Tel Aviv, The Porter Institute for Poetics and Semiotics, Tel Aviv University. (Hebrew)

TOURY, Gideon (1995) : Descriptive Translation Studies and Beyond, Amsterdam/Philadelphia, John Benjamins.

WEISSBROD, Rachel (1989) : Trends in Translation of Prose Fiction from English into Hebrew, 1958-1980, Ph.D. Thesis, Tel Aviv, Tel Aviv University. (Hebrew, English abstract)

Plays (originals and Hebrew translations)

ANOUILH, Jean (1951) : L'invitation au château, Paris, La Table ronde.

ANOUILH, Jean (Stage performance 1957) : Bal ha-ganavim or neshef ha-ganavim, tr. M. Levin, A working text of "Habima" theatre.

BALDWIN, James (1964) : Blues for Mister Charlie, New York, Dial Press.

BALDWIN, James (Stage performance 1965) : bluz le-mister charlie, tr. H. Ben-Ari, A working text of "Habima" theatre.

BECKETT, Samuel (1952) : En attendant Godot, Paris, Éditions de Minuit.

BECKETT, Samuel (Stage performance 1955) : anu mexakim le-mar'el, tr. M. Almaz, A working text of "Zira" theatre.

HANSBERRY, Lorraine (1959) : A Raisin in the Sun, New York, Random House.

HANSBERRY, Lorraine (Stage performance 1960) : tsimuk ba-shemesh, tr. Y. Burla, Ha-merkaz le-tarbut u-lexinux shel ha-histadrut, [Tel Aviv].

IONESCO, Eugène (1954) : Victimes du devoir, Théâtre, Paris, Gallimard, vol. I.

IONESCO, Eugène (Stage performance 1968) : korbenot ha-xova, tr. A. Stav, A working text of "Bimat hakibbutz" theatre.

IONESCO, Eugène (1975a) : Les chaises. Les chaises, suivi de L'impromptu de l'Alma, Paris, Gallimard.

IONESCO, Eugène [the seventies?] : ha-kis'ot, tr. M. Meged, Ha-merkaz le-tarbut u-le-xinux shel ha-histadrut, [Tel Aviv]. 
IONESCO, Eugène (1975b) : Rhinocéros, Paris, Gallimard.

IONESCO, Eugène (Stage performance 1962) : karnafim, tr. N. Aloni, Ha-merkaz le-tarbut u-le-xinux shel hahistadrut, [Tel Aviv].

JONES, Leroi (1964) : Dutchman and The Slave, New York, William Morrow and Company.

JONES, Leroi (Stage performance 1967) : rakevet taxtit, tr. N. Aloni, A working text of "Bimot" theatre.

MILLER, Arthur (1957) : All My Sons. Collected Plays, New York, The Viking Press.

MILLER, Arthur (Stage performance 1949) : kulam hayu banay, tr. B. Tamuz, A working text of "Hacameri" theater.

MILLER, Arthur (1963) : A View from the Bridge. A View from the Bridge; All My sons, Middlesex, Penguin Books.

MILLER, Arthur (Stage performance 1956) : mar'e me-al ha-gesher, tr. A. Meged, Ha-merkaz le-tarbut u-lexinux shel ha-histadrut, [Tel Aviv].

MILLER, Arthur (1971) : The Crucible, Middlesex, Penguin Books.

MILLER, Arthur (Stage performance 1954) : tsed ha-mexashfot, tr. A. Amir, Ha-merkaz le-tarbut u-le-xinux shel ha-histadrut, [Tel Aviv].

O'NEILL, Eugene (1923) : In the Zone. The Moon of the Caribees and Six Other Plays of the Sea, New York, The Modern Library.

O'NEILL, Eugene (the fifties?) : be'ezor ha-mokshim, tr. Y. Burla, Ha-merkaz le-tarbut u-le-xinux shel hahistadrut, [Tel Aviv].

OSBORNE, John (1968) : Look Back in Anger, London, Faber and Faber.

OSBORNE, John (Stage performance 1959) : habet axora be-za'am, tr. T. Carmi, A working text of "Habima" theatre.

PINTER, Harold (1968) : The Caretaker, London, Methuen.

PINTER, Harold (Stage performance 1961) : menahel ha-bayit, tr. C. Glickstein, Ha-merkaz le-tarbut u-le-xinux shel ha-histadrut, [Tel Aviv].

SHAW, George Bernard (1941) : Pygmalion, Middlesex, Penguin Books.

SHAW, George Bernard (Stage performance 1954) : Pygmalion, tr. Y. Ratosh, Ha-merkaz le-tarbut u-le-xinux shel ha-histadrut, [Tel Aviv].

WILliAMS, Tennessee (1968) : The Rose Tattoo. The Rose Tattoo; Camino Real, Middlesex, Penguin Books.

WILLIAMS, Tennessee (stage performance 1971) : ha-shoshana ha-meku'aka'at, tr. Y. Burla, A working text of "Habima" theatre. 